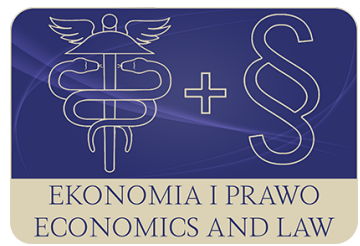

EKONOMIA I PRAWO. ECONOMICS AND LAW

Volume 16, Issue 2, June 2017

p-ISSN 1898-2255, e-ISSN 2392-1625

www.economicsandlaw.pl

ORIGINAL ARTICLE

received 13.06.2017; revised 25.06.2017; accepted 30.06.2017

Citation: Polcyn, J. (2017). The number of pupils and educational effects in comprehensive secondary schools. Ekonomia i Prawo. Ecomomics and Law, 16(2): 185-200. doi:10.12775/EiP.2017.013

\title{
The number of pupils and educational effects in comprehensive secondary schools
}

\author{
JAN POLCYN \\ Stanisław Staszic University of Applied Sciences in Piła, Economics Faculty, ul. Podchorążych 10, \\ 64-920 Piła, Poland \\ $\square$ Jan.Polcyn@pwsz.pila.pl
}

\begin{abstract}
Motivation: There may be a significant correlation between the number of pupils in a school and their learning performance. Some studies point to the negative impact of schools with a large number of pupils on the educational results achieved. At the same time, the demographic crisis that has been deepening steadily for several years now represents an important motivation for rationalising the existing network of schools.

Aim: The aim of the study was to determine the optimum size of schools based on the criterion of examination results expressed through educational value added.

Results: The analyses conducted in this study showed that the comprehensive secondary schools with over 600 pupils had the highest learning outcomes as expressed through educational value added. The lowest educational effectiveness was found in schools with less than 150 pupils. A dependency was discovered whereby the effectiveness of education increases as the number of pupils grows. Due to the lack of data concerning examination results in schools with more than 1,000 pupils (value indicated in American studies as the threshold value for positive learning outcomes), it was not possible to determine

the maximum number of pupils that guarantees satisfactory learning outcomes.
\end{abstract}

Keywords: number of pupils in a school; educational value added (EVA); comprehensive secondary school; socio-cultural capital

JEL: A20, A21, A29 


\section{Introduction}

The key question to be asked when evaluating the effectiveness of educational facilities concerns the learning outcomes. Moreover, the public spending on education in Poland amounts to about 6\% GDP. Such an amount of spending provides a particularly strong argument for seeking the ways to rationalise the expenditure allocated to this area of public activity.

The question seems even more relevant in view of the deepening demographic crisis. This is directly related to the issue of the optimum school size that would ensure the desirable learning environment and simultaneously minimise the administrative costs of running an educational facility.

The problem of school size should be considered in relation to the educational stage, since the negative impact of school size on learning outcomes may be linked to a particular stage of education.

In view of those considerations, the question should be asked: How big should a school be in order to ensure the optimum learning outcomes? Based on that question, the research objectives of this article were formulated. Thus, the purpose of the study was to determine the optimum size of a school based on the criterion of examination results expressed through educational value added.

The priority goal of educational activity should be to achieve the highest quality of education possible in a given situation. This objective was also confirmed by the report of the Polish Supreme Audit Office: 'The Supreme Audit Office regards the quality of school education as one of the most important longterm factors affecting the development of the state and the living standard of its citizens' (NIK, 2014, p. 7). Bearing this in mind, any measures aimed at rationalising the network of education facilities should take into account the effect of that rationalisation on learning outcomes.

\section{Method of the research}

The data in this study was analysed on the basis of the 3-year (2013-2015) educational value added indicator for all comprehensive secondary schools in Poland $(\mathrm{N}=1,943)$. Data for the analysis was obtained from the Section of Educational Value Added of the Educational Research Institute in Warsaw.

The comprehensive secondary schools under study were grouped into 5 classes according to the average number of graduates per each year of analysis: class A (up to 50 graduates), class B (51-100 graduates), class C (101-150 graduates), class D (151-200 graduates), and class E (above 250 graduates). Based on the quantitative analysis of educational value added in comprehensive secondary schools, the percentage of schools with a positive and negative educational value added indicator was determined for the examined population. Moreover, the mean educational value added indicator was calculated for each 
class of comprehensive secondary schools defined by the average annual number of graduates.

Next, a univariate ANOVA was performed, where the dependent variables were the scores of educational value added for matura examinations in the Polish language, humanities, mathematics, and mathematical and natural sciences. The classes defined by the average number of graduates served as the qualitative predictor for the analysis. Multivariate significance tests were applied, including Pillai's Trace, Wilks' Lambda, Hotelling's Trace, and Roy's Root, in order to adopt/reject the null hypothesis assuming the equality of vectors of average graduate numbers in favour of an alternative hypothesis according to which the vectors differed significantly (which would confirm the research hypothesis put forward in the introduction). Subsequently, a post-hoc analysis was conducted using Tukey's HSD tests for significant dependent variables (according to univariate results) in order to assess which classes of the qualitative predictor significantly determine the variation of the dependent variables. Next, contrasts were computed for qualitative predictor classes in order to specify what portion of the qualitative predictor can be attributed to a given contrast. The sum of squares (SS), or the variation attributed to a contrast, was calculated using formula 1 and divided by the $S S$ for a given dependent variable in all predictor classes (Stanisz, 2007, p. 367):

$$
S S_{L}=\frac{\bar{L}^{2}}{\frac{1}{n} \sum_{i=1}^{k} c_{i}^{2}},
$$

where:

$\bar{L}$ - value of contrast;

$n$ - number of replications (measurements in a group);

$c_{i}$ - weights describing a contrast.

Values of contrasts were calculated using formula (2):

$$
\bar{L}=\sum_{i=1}^{k} c_{i} \bar{X}_{i},
$$

where $\bar{x}_{1}, \ldots, \bar{x}_{k}$, are the means of samples.

Finally, the so-called indicator $\omega$ was calculated which is an estimator of the variance of the dependent variable explained by the independent variable for the number of graduates (as significant dependent variables). The indicator was calculated using formula (Stanisz, 2007, p. 367):

$$
\omega=\frac{\left(S S_{\text {effect }}-p \cdot M S_{\text {error }}\right)}{S S_{\text {effect }}+S S_{\text {error }}+M S_{\text {error }}},
$$


where:

$S S_{\text {effect }}$ - intergroup sum of squared differences between the means of variables for particular classes of the predictor and their global average (measure of the total variation of means);

$p$ - degrees of freedom of the qualitative predictor;

$S S_{\text {eror }}$ - measure of random variation, i.e. the sum of squared differences between the results of observation and the mean value for a class;

$M S_{\text {error }}$ - mean sums of squared errors.

Indicator $\omega$ is used to assess what percentage of variation (variance) of a dependent variable can be attributed to the qualitative predictor; in this case the number of comprehensive secondary school graduates.

\section{The impact of pupil number in a school on learning outcomes}

The structure and quality of school environment is generally considered to be vital for creating favourable learning conditions and encouraging parental involvement. It is believed that large, impersonal and highly bureaucratised schools create many barriers to effective learning (Meier, 1997, pp. 194-208). Case studies investigating the effectiveness of schools point to the importance of school size (Hunt, 1990, pp. 252-254). At the same time, an improvement in pupils' educational attainment was observed in small comprehensive secondary schools (Darling-Hammond et al., 2002, pp. 639-673).

It is a popular belief that pupils attending smaller schools achieve better learning outcomes. In particular, attention is drawn to better learning conditions in those schools. A study conducted in New York took into account interpersonal relationships, educational outcomes, social attitudes and the level of safety. The results of the study suggest that the pupils attending a small school perceive it as a better learning environment needed for the accomplishment of their own objectives. However, the studies cited above did not substantiate the thesis that small schools provide a better learning environment than large ones. The findings represent a challenge for the widespread belief that better conditions offered by small schools contribute to higher learning outcomes (Schwartz et al., 2016, pp. 272-290)

The research on the optimum size of schools yields varied results. A study on educational value added conducted in North Carolina pointed to the lack of cause/effect relationship between school size and the learning outcomes achieved by the pupils. It was noted, however, that school size plays an important role for disabled pupils (Gershenson \& Langbein, 2015, pp. 135S-155S).

Some research findings suggest that the proper pupil/teacher ratio is an important factor reducing the level of crime. However, those parameters are not linked to school size. The level of crime amongst pupils is to a greater degree determined by the social capital derived from their family background than by the actual school size (Gottfredson \& DiPietro, 2011, pp. 69-89). 
The studies discussed above refer to a completely different part of the world. However, similar studies were also conducted in Ukraine, a country that is geographically close to Poland. The Ukrainian studies highlight the need to rationalise the school network due to demographic decline. In this context, a question arises. Should we maintain smaller schools and expect better exam results? Independent tests revealed that school size has a relatively small impact on the learning outcomes in secondary schools. This observation provides an argument in favour of rationalising the network of schools (Coupe et al., 2016, pp. 329-351).

The US government recommended the consolidation of schools, especially in rural areas, in order to improve school effectiveness. However, this policy was criticised. It was argued that school consolidation would result in the deterioration of learning conditions. Moreover, such situations usually raise questions concerning the economies of scales. One of the arguments in favour of school consolidation are the savings resulting from reduced costs of administration due to the transfer of schools with less than 500 pupils to the districts that provide schooling for about 3,000 to 4,000 pupils. This solution, however, goes contrary to the conclusions of studies on educational production function. The studies advocate maintaining primary schools with $300-500$ pupils and secondary schools with 500-900 pupils. The authors of those studies believe that such school sizes could balance the advantages arising from the school size with the potential negative effects of large schools (Andrews et al., 2002, pp. 245-262).

In Chicago, research on the size of comprehensive secondary schools was conducted over four years in order to assess the impact of transformation of large, traditional schools into small, autonomous ones. It was shown that the analysed schools had a lower drop-out rate. The authors of the study did not find any strong arguments to justify school size reduction, which implies there is no correlation between school size and learning outcomes (Kahne et al., 2008, pp. 281-315).

An examination of 57 results of empirical school size research carried out in the USA after 1990 reveals that primary schools for pupils from socially and economically disadvantaged backgrounds should ideally be limited in size to 300 pupils. Primary schools for pupils from advantaged backgrounds should be limited in size to 500 pupils. The size of middle schools should be limited to 600 pupils, whereas secondary school serving youth from socially and economically diverse backgrounds and relatively advantaged backgrounds should not exceed 1,000 pupils (Leithwood \& Jantzi, 2009, pp. 464-490).

Other studies investigating the relationship between school size and learning achievements show that a comprehensive secondary school should ideally serve between 600-900 pupils. Pupils in smaller schools demonstrated lower academic performance; a similar situation was observed in schools serving over 2,100 pupils. It should be noted that the educational process was found 
to be more equitable in very small schools where it was linked to the pupil's socio-economic status (Lee \& Smith, 1997, pp. 205-227).

\section{The size of comprehensive secondary schools in Poland and learning outcomes}

The mean educational value added provides an objective measure of school effectiveness. It is calculated for each pupil separately and the sum of scores of that indicator can be used to evaluate a school's effectiveness. The desired score of that indicator should be a positive value (neutral value is expressed through zero). A negative educational value added means that the teaching process does not make the proper use of the pupils' educational level. The assumptions concerning educational value added were used to estimate the effectiveness of schools depending on the school size which, in the present study, was expressed through the average annual number of graduates during the research period.

An evaluation of school effectiveness on the basis of educational value added indicator shows that the schools with the smallest number of graduates (class $\mathrm{A}$ and B) have an undesired level of learning outcomes. This is evidenced by the relatively high percentage of schools with negative educational value added and negative mean educational value added. In class $\mathrm{A}$, about $70 \%$ to approximately $82 \%$ schools had a negative value added score. In class B, there were about $68 \%$ to $74 \%$ such schools. A similar correlation was found with respect to mean educational value added which oscillated between -3.49010 and -1.32224 in the two classes mentioned above (table 1.).

The data given in table 1 suggests that a school's effectiveness increases as the number of pupils in the school increases. A limit of 101-150 graduates represents the threshold value between ineffective and effective educational process. An analysis of final examination results in schools with such a number of graduates reveals that $50 \%$ of schools from that group (class C) have positive educational value added score. Moreover, mean educational value added has a positive score for examination results in mathematics, and mathematical and natural sciences (table 1 ).

The vast majority of schools in the next two classes, i.e. class D (151 graduates) and class E (above 201 graduates), achieved a positive educational value added score. About $65 \%$ of schools in class D had a positive educational value added for Polish language exams, and over $85 \%$ of schools achieved a positive value added for mathematical and natural sciences exams (table 1). Moreover, both those classes of schools recorded a regular increase in mean educational value added. The increase was from 0.79297 for Polish language exams in class $\mathrm{D}$ to 2.25196 for mathematical and natural sciences exams in class E (table 1).

The three-year education cycle in Polish comprehensive secondary schools permits the following estimation of the number of pupils in a school: up to 150 in class A, from 151 to 300 in class B, from 301 to 450 in class C, from 451 
to 600 in class D, and above 600 in class E. Under Polish conditions, it should be assumed that an effective learning environment is provided by schools serving a minimum of 450 pupils. However, schools with more than 600 pupils achieve even better learning outcomes. The proposed school sizes are in line with the results of the American studies quoted above (Leithwood \& Jantzi, 2009, pp. 464-490; Lee \& Smith, 1997, pp. 205-227; Andrews et al., 2002, pp. 245-262).

A spatial analysis of the distribution of classes with the highest learning outcomes (D and E) shows that the schools belonging to those classes are usually located in large agglomerations, or cities. Such a correlation may indicate the presence of additional factors that strongly affect the quality of educational processes and have a particularly beneficial effect on those processes in large urban centres (figure 1).

In this context, one cannot overlook the importance of what social scientists refer to as reproduction processes. Those processes are related to the phenomenon of habitus which is understood as a set of trends, dispositions, perceptions of values, and attitudes reflected in human habits (Bourdieu \& Passeron, 2006, p. 13).

Special attention is given to the process of educational selections and the associated membership in the social class of origin which determines the living standards, the ethos as well as the hereditary social and cultural capital (Bourdieu \& Passeron, 2006, p. 25).

Problems that may be attributable to young people's social and cultural capital were also confirmed by the report drawn up by the Supreme Audit Office, according to which 'pupils in middle and secondary-school show low motivation for participation in school activities which, alongside behavioural issues, leads to deterioration in pupils' learning outcomes. The pupils surveyed by the Supreme Audit Office reported that they would achieve better learning results if the teachers could get them interested in their subject' (NIK, 2014, p. 9).

As a next step of the study, statistical analyses were conducted between the classes of schools defined by the number of graduates. The analyses began with multivariate significance tests which rejected the null hypothesis about the equality of vectors of mean educational value added for particular classes of schools in favour of an alternative hypothesis according to which the vectors differed significantly. Those findings confirmed the assumption that those classes differ significantly among themselves in terms of educational value added and validated the correctness of further considerations (table 2).

Furthermore, Box's M test was performed which confirmed the homogeneity of covariances in a multivariate space. This means that there are significant differences between the variance and covariance matrices in different subclasses of the intergroup system for the currently analysed effect.

The univariate results point to significant variance of all four variables across the analysed classes of schools, i.e. educational value added in the Polish language, humanities, mathematics, mathematical and natural sciences (table 3). 
Post-hoc tests demonstrated that a change in the size of secondary schools, except for the change from class $\mathrm{D}$ to $\mathrm{E}$, has a significant impact on the mean educational value added in humanities and mathematics. As regards the educational value added in mathematical and natural sciences, it is also significantly affected by the change from class D to E (tables 4-7).

An analysis of contrasts was carried out which demonstrated the relative importance of the changes in size classes defined by the number of graduates (tables 8-10).

The analysis demonstrated that changing the class of a school from A to E based on the number of graduates accounts for $55 \%$ of the difference in educational value added in the Polish language. Changing the class from $\mathrm{B}$ to $\mathrm{E}$ accounts for $33 \%$ of the difference in educational value added in Polish, whereas the change from $\mathrm{C}$ to E explains $10 \%$ of the difference (table 8 ). Only $2 \%$ of the difference between class $\mathrm{D}$ and $\mathrm{E}$ has been explained, but this value is not statistically significant, as has already been confirmed by Tukey's HSD test (table 4 ). The indicator $\omega$ calculated for the group of contrasts shows that the classes of schools defined by the number of graduates account for only $12 \%$ of the variation of educational value added in the Polish language.

The analysis of contrasts demonstrated that changing the class of a school from $\mathrm{A}$ to $\mathrm{E}$ based on the number of graduates accounts for $54 \%$ of the difference in educational value added in the humanities. Changing the class from $\mathrm{B}$ to $\mathrm{E}$ accounts for $34 \%$ of the difference in educational value added in humanities, whereas the change from C to E explains $10 \%$ of the difference (table 9). Only $2 \%$ of the difference between class D and $\mathrm{E}$ has been explained, but this value is not statistically significant, as has already been confirmed by Tukey's HSD test (table 5). The indicator $\omega$ calculated for the group of contrasts shows that the classes of schools defined by the number of graduates account for only $15 \%$ of the variation of educational value added in humanities.

The scores of educational value added in humanities to a large extent coincide with the scores of educational value added achieved for final exams in the Polish language (tables 8-9).

The analysis of contrasts demonstrated that changing the class of a school from $\mathrm{A}$ to $\mathrm{E}$ based on the number of graduates accounts for $61 \%$ of the difference in educational value added in mathematics. Changing the class from $\mathrm{B}$ to $\mathrm{E}$ accounts for $32 \%$ of the difference in educational value added in mathematics, whereas the change from $\mathrm{C}$ to $\mathrm{E}$ explains $7 \%$ of the difference (table 10). The contrast between class $\mathrm{D}$ and $\mathrm{E}$ does not explain the difference in educational value added, which has also been confirmed by Tukey's HSD test (table 6). The indicator $\omega$ calculated for the group of contrasts shows that the classes of schools defined by the number of graduates account for only $26 \%$ of the variation of educational value added in mathematics.

The analysis of contrasts demonstrated that changing the class of a school from $\mathrm{A}$ to $\mathrm{E}$ based on the number of graduates accounts for $60 \%$ of the difference in educational value added in mathematical and natural sciences. Chang- 
ing the class from B to E accounts for $32 \%$ of the difference in educational value added in smathematical and natural sciences, whereas the change from $\mathrm{C}$ to E explains $9 \%$ of the difference. The contrast between class D and E does not explain the difference in educational value added (table 1l). The indicator $\omega$ calculated for the group of contrasts shows that the classes of schools defined by the number of graduates account for only $29 \%$ of the variation of educational value added in mathematical and natural sciences.

\section{Conclusion}

The analyses conducted in this study showed that the comprehensive secondary schools with over 600 pupils were characterised by the highest learning outcomes as expressed through educational value added. Those findings have also been confirmed by the American studies quoted above.

The dependencies discovered in this study may provide guidance to local government bodies (poviats) concerning the development of school network, especially in the context of demographic decline. It should be remembered, however, that the effectiveness of teaching does not solely depend on the number of pupils in school, but is also affected by other factors belonging to the sphere of sociocultural capital and economic capital.

Nonetheless, the analyses investigating all comprehensive secondary schools in Poland over a 3-year research period revealed that the school size has no negative impact on the quality of teaching (on the contrary, positive impact was identified), which is a sufficiently strong conclusion to be considered when undertaking the modification of the existing school network.

Due to the lack of data concerning examination results in schools with more than 1,000 pupils (number indicated in American studies as the threshold value for positive learning outcomes), it was not possible to determine the maximum number of pupils in a school that would guarantee satisfactory learning outcomes (Leithwood \& Jantzi, 2009, pp. 464-490).

\section{References}

Andrews, M., Duncombe, W., \& Yinger, J. (2002). Revisiting economies of size in American education: are we any closer to a consensus? Economics of Education Review, 21(3). doi:10.1016/s0272-7757(01)00006-1.

Bourdieu, P., \& Passeron, J.C. (2006). Reprodukcja. Elementy teorii systemu nauczania. Warszawa: PWN.

Coupe, T., Olefir, A., \& Alonso, J.D. (2016). Class size, school size and the size of the school network. Education Economics, 24(3). doi:10.1080/09645292. 2015.1015405.

Darling-Hammond, L., Ancess, J., \& Ort, S.W. (2002). Reinventing high school: outcomes of the Coalition Campus Schools Project. American Educational Research Journal, 39(3). doi:10.3102/00028312039003639. 
Gershenson, S., \& Langbein, L. (2015). The effect of primary school size on academic achievement. Educational Evaluation and Policy Analysis, 37(1). doi:10.3102/0162373715576075.

Gottfredson, D.C., \& Dipietro, S.M. (2011). Schoolsize, social capital, and student victimization. Sociology of Education, 84(1). doi:10.1177/0038040710392718.

Hunt, F.J. (1990). Review of the book Reducing the risk - school as communities of support by G.G. Wehlage, R.A. Rutter, G.A. Smith, N. Lesko, \& R.R. Fernandez. Journal of Sociology, 26(2).

Kahne, J.E., Sporte, S.E., De La Torre, M., \& Easton, J.Q. (2008). Small high schools on a larger scale: the impact of school conversions in Chicago. Educational Evaluation and Policy Analysis, 30(3). doi:10.3102/0162373708319184.

Lee, W.E., \& Smith, J.B. (1997). High school size: which works best and for whom? Educational Evaluation and Policy Analysis, 19(3). doi:10.3102/01623737019003205.

Leithwood, K., \& Jantzi, D. (2009). A review of empirical evidence about school size effects: a policy perspective. Review of Educational Research, 79(1). doi:10.3102/0034654308326158.

Meier, D.W. (1997). Can the odds be changed? Educational Policy, 11(2).

NIK. (2014). Efekty ksztatcenia w szkotach publicznych i niepublicznych o uprawnieniach szkót publicznych. Retrieved 13.06.2017 from http://www.kuratorium. bydgoszcz.uw.gov.pl.

Schwartz, A.E., Stiefel, L., \& Wiswall, M. (2016). Are all schools created equal? Learning environments in small and large public high schools in New York City. Economics of Education Review, 52(3). doi:10.1016/j. econedurev.2016.03.007.

Stanisz, A. (2007). Przystępny kurs statystyki z zastosowaniem STATISTICA PL na przyktadach z medycyny. Tom 1. Statystki podstawowe. Kraków: StatSoft.

\section{Acknowledgements}

Author contributions: author has given an approval to the final version of the article.

Note: the results of this study were presented at 9th International Conference on Applied Economics Contemporary issues in Economy (Toruń, June 22-23, Torun, Poland). 


\section{Appendix}

Table 1.

Synthetic summary of matura exam results in comprehensive secondary schools from 2013 to 2015

\begin{tabular}{|c|c|c|c|c|c|c|}
\hline \multirow{2}{*}{$\begin{array}{c}\text { Number } \\
\text { of pupils } \\
\text { taking matura } \\
\text { exam } \\
\text { (Class) }\end{array}$} & \multicolumn{3}{|c|}{ Polish language } & \multicolumn{3}{|c|}{ Humanities } \\
\hline & $\begin{array}{c}\text { Number } \\
\text { of schools } \\
\text { with positive } \\
\text { EVA }\end{array}$ & $\begin{array}{c}\text { Number } \\
\text { of schools } \\
\text { with negative } \\
\text { EVA }\end{array}$ & Mean EVA & $\begin{array}{c}\text { Number } \\
\text { of schools } \\
\text { with positive } \\
\text { EVA }\end{array}$ & $\begin{array}{c}\text { Number } \\
\text { of schools } \\
\text { with negative } \\
\text { EVA }\end{array}$ & Mean EVA \\
\hline \multirow{2}{*}{$\leq 50(\mathrm{~A})$} & 250 & 574 & \multirow{2}{*}{-2.09229} & 237 & 587 & \multirow{2}{*}{-2.29663} \\
\hline & $(30.34 \%)$ & $(69.66 \%)$ & & $(28.76 \%)$ & $(71.24 \%)$ & \\
\hline \multirow{2}{*}{ 51-100 (B) } & 128 & 269 & \multirow{2}{*}{-1.32224} & 114 & 283 & \multirow{2}{*}{-1.52058} \\
\hline & $(32.24 \%)$ & $(67.75 \%)$ & & $(28.72 \%)$ & (71.28\%) & \\
\hline \multirow{2}{*}{$101-150(C)$} & 154 & 156 & \multirow{2}{*}{-0.07465} & 153 & 157 & \multirow{2}{*}{-0.05903} \\
\hline & $(49.68 \%)$ & $(50.32 \%)$ & & $(49.35 \%)$ & $(50.65 \%)$ & \\
\hline \multirow{2}{*}{$151-200(\mathrm{D})$} & 170 & 89 & \multirow{2}{*}{0.79297} & 174 & 85 & \multirow{2}{*}{0.93170} \\
\hline & $(65.63 \%)$ & $(34.36 \%)$ & & $(67.18 \%)$ & $(32.82 \%)$ & \\
\hline \multirow{2}{*}{$\geq 201$ (E) } & 111 & 42 & \multirow[b]{2}{*}{1.53915} & 115 & 38 & \multirow{2}{*}{1.68386} \\
\hline & $(72.55 \%)$ & $(27.45 \%)$ & & $(75.16 \%)$ & (24.84\%) & \\
\hline \multirow{2}{*}{$\begin{array}{l}\text { Number } \\
\text { of pupils } \\
\text { taking matura } \\
\text { exam } \\
\text { (Class) }\end{array}$} & \multicolumn{3}{|c|}{ Mathematics } & \multicolumn{3}{|c|}{ Mathematical and natural sciences } \\
\hline & $\begin{array}{c}\text { Number } \\
\text { of schools } \\
\text { with positive } \\
\text { EVA }\end{array}$ & $\begin{array}{c}\text { Number } \\
\text { of schools } \\
\text { with negative } \\
\text { EVA }\end{array}$ & Mean EVA & $\begin{array}{c}\text { Number } \\
\text { of schools } \\
\text { with positive } \\
\text { EVA }\end{array}$ & $\begin{array}{c}\text { Number } \\
\text { of schools } \\
\text { with negative } \\
\text { EVA }\end{array}$ & Mean EVA \\
\hline \multirow{2}{*}{$\leq 50(\mathrm{~A})$} & 150 & 674 & \multirow{2}{*}{-3.49010} & 149 & 675 & \multirow{2}{*}{-3.87027} \\
\hline & $(18.20 \%)$ & $(81.79 \%)$ & & $(18.08 \%)$ & $(81.92 \%)$ & \\
\hline \multirow{2}{*}{ 51-100 (B) } & 110 & 287 & \multirow{2}{*}{-2.02076} & 103 & 294 & \multirow{2}{*}{-2.33627} \\
\hline & $(22.71 \%)$ & $(72.29 \%)$ & & $(25.94 \%)$ & $(74.06 \%)$ & \\
\hline \multirow{2}{*}{$101-150(C)$} & 164 & 146 & \multirow{2}{*}{0.07616} & 168 & 142 & \multirow{2}{*}{0.05806} \\
\hline & $(52.90 \%)$ & $(47.10 \%)$ & & $(54.19 \%)$ & $(45.81 \%)$ & \\
\hline \multirow{2}{*}{$151-200(\mathrm{D})$} & 189 & 70 & \multirow{2}{*}{1.54958} & 202 & 57 & \multirow{2}{*}{1.70452} \\
\hline & $(72.97 \%)$ & $(27.03 \%)$ & & (77.99\%) & $(22.01 \%)$ & \\
\hline \multirow[b]{2}{*}{$\geq 201$ (E) } & 124 & 29 & & 131 & 22 & \\
\hline & $(81.05 \%)$ & $(18.95 \%)$ & 1.91778 & $(85.62 \%)$ & $(14.38 \%)$ & 2.25196 \\
\hline
\end{tabular}

Source: own work based on the data from the Educational Research Institute.

Table 2.

Multivariate significance tests

\begin{tabular}{lcccccc}
\hline \multirow{2}{*}{$\begin{array}{l}\text { Classes by } \\
\text { the number }\end{array}$} & Test & Value & $F$ & Effect df & Error $d f$ & $p$ \\
\cline { 2 - 7 } of pupils & Wilks' Lambda & 0.05557 & 445.963 & 20 & 6415.302 & 0.00 \\
taking matura & Pillai's Trace & 0.96377 & 122.969 & 20 & 7748.000 & 0.00 \\
exam & Hotelling's Trace & 16.64979 & 1608.786 & 20 & 7730.000 & 0.00 \\
& Roy's Root & 16.62900 & 6442.076 & 5 & 1937.000 & 0.00 \\
\hline
\end{tabular}

Source: own work using Statistica software v.12, based on the data from the Educational Research Institute. 
Table 3.

Univariate results for dependent variables expressed through educational value added

\begin{tabular}{|c|c|c|c|c|c|c|c|c|c|}
\hline \multirow{2}{*}{ Specification } & \multirow{2}{*}{$\begin{array}{l}\text { Degrees } \\
\text { of freedom }\end{array}$} & SS & MS & $F$ & $p$ & SS & MS & $F$ & $p$ \\
\hline & & \multicolumn{4}{|c|}{ Polish language } & \multicolumn{4}{|c|}{ Humanities } \\
\hline Intercept & 1 & 77.14 & 77.14 & 6.780 & 0.009 & 91.58 & 91.58 & 8.083 & 0.004 \\
\hline $\begin{array}{l}\text { Classes by } \\
\text { the number } \\
\text { of pupils taking } \\
\text { matura exam }\end{array}$ & 4 & 3102.4 & 775.61 & 68.174 & 0.000 & 3833.2 & 958.31 & 84.590 & 0.000 \\
\hline Error & 1938 & 22048.2 & 11.38 & - & - & 21955.3 & 11.33 & - & - \\
\hline Total & 1942 & 25150.6 & - & - & - & 25788.5 & - & - & - \\
\hline Specification & $\begin{array}{c}\text { Degrees } \\
\text { of freedom }\end{array}$ & \multicolumn{4}{|c|}{ Mathematics } & \multicolumn{4}{|c|}{ Mathematical and natural sciences } \\
\hline Intercept & 1 & 223.01 & 223.01 & 18.678 & 0.000 & 276.85 & 276.85 & 20.781 & 0.000 \\
\hline $\begin{array}{l}\text { Classes by } \\
\text { the number } \\
\text { of pupils taking } \\
\text { matura exam }\end{array}$ & 4 & 8336.1 & 2084.02 & 174.55 & 0.000 & 10391.5 & 2597.87 & 195.00 & 0.000 \\
\hline Error & 1938 & 23138.8 & 11.94 & - & - & 25818.8 & 13.32 & - & - \\
\hline Total & 1942 & 31474.9 & - & - & - & 36210.3 & - & - & - \\
\hline
\end{tabular}

Source: own work using Statistica software v.12, based on the data from the Educational Research Institute.

Table 4.

Tukey's HSD test - dependent variable 'educational value added in the Polish language'

\begin{tabular}{cccccrrr}
\hline \multicolumn{7}{c}{ Approximate probability for post-hoc tests; Error: Intergroup $\mathrm{MS}=11.377, \mathrm{df}=1938$} \\
\hline Item no. & $\begin{array}{c}\text { Classes by the number of pupils taking } \\
\text { matura exam }\end{array}$ & $\mathrm{A}$ & $\mathrm{B}$ & $\mathrm{C}$ & $\mathrm{D}$ & $\mathrm{E}$ \\
\hline l. & $\mathrm{A}$ & - & 0.001753 & 0.000017 & 0.000017 & 0.000017 \\
2. & $\mathrm{~B}$ & 0.001753 & - & 0.000027 & 0.000017 & 0.000017 \\
3. & $\mathrm{C}$ & 0.000017 & 0.000027 & - & 0.019082 & 0.000029 \\
4. & $\mathrm{D}$ & 0.000017 & 0.000017 & 0.019082 & - & 0.191281 \\
5. & $\mathrm{E}$ & 0.000017 & 0.000017 & 0.000029 & 0.191281 & - \\
\hline
\end{tabular}

Source: own work using Statistica software v.12, based on the data from the Educational Research Institute. 
Table 5.

Tukey's HSD test - dependent variable 'educational value added in humanities'

\begin{tabular}{|c|c|c|c|c|c|c|}
\hline \multicolumn{7}{|c|}{ Approximate probability for post-hoc tests; Error: Intergroup $M S=11.329, d f=1938$} \\
\hline Item no. & $\begin{array}{l}\text { Classes by the number of pupils taking } \\
\text { matura exam }\end{array}$ & A & B & $\mathrm{C}$ & $\mathrm{D}$ & E \\
\hline 1. & A & - & 0.001518 & 0.000017 & 0.000017 & 0.000017 \\
\hline 2. & B & 0.001518 & - & 0.000017 & 0.000017 & 0.000017 \\
\hline 3. & $\mathrm{C}$ & 0.000017 & 0.000017 & - & 0.004317 & 0.000019 \\
\hline 4. & $\mathrm{D}$ & 0.000017 & 0.000017 & 0.004317 & - & 0.182776 \\
\hline 5. & E & 0.000017 & 0.000017 & 0.000019 & 0.182776 & - \\
\hline
\end{tabular}

Source: own work using Statistica software v.12, based on the data from the Educational Research Institute.

Table 6.

Tukey's HSD test - dependent variable 'educational value added in mathematics'

\begin{tabular}{cccccccr}
\hline \multicolumn{7}{c}{ Approximate probability for post-hoc tests; Error: Intergroup $\mathrm{MS}=11.940, \mathrm{df}=1938$} \\
\hline Item no. & $\begin{array}{c}\text { Classes by the number of pupils taking } \\
\text { matura exam }\end{array}$ & $\mathrm{A}$ & $\mathrm{B}$ & $\mathrm{C}$ & $\mathrm{D}$ & $\mathrm{E}$ \\
\hline l. & $\mathrm{A}$ & - & 0.000017 & 0.000017 & 0.000017 & 0.000017 \\
2. & $\mathrm{~B}$ & 0.000017 & - & 0.000017 & 0.000017 & 0.000017 \\
3. & $\mathrm{C}$ & 0.000017 & 0.000017 & - & 0.000021 & 0.000018 \\
4. & $\mathrm{D}$ & 0.000017 & 0.000017 & 0.000021 & - & 0.834329 \\
5. & $\mathrm{E}$ & 0.000017 & 0.000017 & 0.000018 & 0.834329 & \\
\hline
\end{tabular}

Source: own work using Statistica software v.12, based on the data from the Educational Research Institute.

Table 7.

Tukey's HSD test - dependent variable 'educational value added in mathematical and natural sciences'

\begin{tabular}{cccccccc}
\hline \multicolumn{7}{c}{ Approximate probability for post-hoc tests; Error: Intergroup } & MS=290.67, $d f=1938$ \\
\hline Item no. & $\begin{array}{c}\text { Classes by the number of pupils taking } \\
\text { matura exam }\end{array}$ & $\mathrm{A}$ & $\mathrm{B}$ & $\mathrm{C}$ & $\mathrm{D}$ & $\mathrm{E}$ \\
\hline l. & $\mathrm{A}$ & - & 0.000017 & 0.000017 & 0.000017 & 0.000017 \\
2. & $\mathrm{~B}$ & 0.000017 & - & 0.000017 & 0.000017 & 0.000017 \\
3. & $\mathrm{C}$ & 0.000017 & 0.000017 & - & 0.000017 & 0.000017 \\
4. & $\mathrm{D}$ & 0.000017 & 0.000017 & 0.000017 & - & 0.000017 \\
5. & $\mathrm{E}$ & 0.000017 & 0.000017 & 0.000017 & 0.000017 & - \\
\hline
\end{tabular}

Source: own work using Statistica software v.12, based on the data from the Educational Research Institute. 
Table 8.

Evaluation of contrasts for classes by the number of pupils taking matura exam dependent variable 'educational value added in the Polish language'

\begin{tabular}{|c|c|c|c|c|c|c|}
\hline \multirow[b]{2}{*}{ Specification } & \multicolumn{6}{|c|}{ Educational value added in the Polish language } \\
\hline & Evaluation & $\begin{array}{l}\text { Standard } \\
\text { error }\end{array}$ & $t$ & $p$ & $\begin{array}{c}\text { Confidence limit } \\
-95.00 \%\end{array}$ & $\begin{array}{l}\text { Confidence limit } \\
\quad+95.00 \%\end{array}$ \\
\hline $\begin{array}{l}\text { CONTR. } 1 \\
\text { (A vs. E, i.e. } 1 ; 0 ; 0 ; 0 ;-1 \text { ) }\end{array}$ & -3.631 & 0.2969 & -12.230 & 0.0000 & -4.214 & -3.049 \\
\hline *SScontrast/SSeffect & & & $0.33(55 \%$ & & & \\
\hline $\begin{array}{l}\text { CONTR. } 2 \\
\text { (B vs. E, i.e. 0;1;0;0;-1) }\end{array}$ & -2.861 & 0.3209 & -8.915 & 0.0000 & -3.491 & -2.232 \\
\hline *SScontrast/SSeffect & & & $0.20(33 \%$ & & & \\
\hline $\begin{array}{l}\text { CONTR. } 3 \\
(\mathrm{C} \text { vs. E, i.e. } 0 ; 0 ; 1 ; 0 ;-1)\end{array}$ & -1.614 & 0.3332 & -4.843 & 0.0000 & -2.267 & -0.960 \\
\hline *SScontrast/SSeffect & & & $0.06(10 \%$ & & & \\
\hline $\begin{array}{l}\text { CONTR. } 4 \\
\text { (D vs. E, i.e. } 0 ; 0 ; 0 ; 1 ;-1 \text { ) }\end{array}$ & -0.746 & 0.3439 & -2.170 & 0.0302 & -1.421 & -0.072 \\
\hline *SScontrast/SSeffect & & & $0.01(2 \%$ & & & \\
\hline
\end{tabular}

Source: own work using Statistica software v.12, based on the data from the Educational Research Institute.

Table 9.

Evaluation of contrasts for classes by the number of pupils taking matura exam dependent variable 'educational value added in humanities'

\begin{tabular}{|c|c|c|c|c|c|c|}
\hline \multirow[b]{2}{*}{ Specification } & \multicolumn{6}{|c|}{ Educational value added in humanities } \\
\hline & Evaluation & $\begin{array}{l}\text { Standard } \\
\text { error }\end{array}$ & $t$ & $p$ & $\begin{array}{c}\text { Confidence limit } \\
-95.00 \%\end{array}$ & $\begin{array}{l}\text { Confidence limit } \\
+95.00 \%\end{array}$ \\
\hline $\begin{array}{l}\text { CONTR. } 1 \\
\text { (A vs. E, i.e. 1;0;0;0;-1) }\end{array}$ & -3.980 & 0.2962 & -13.434 & 0.0000 & -4.562 & -3.399 \\
\hline *SScontrast/SSeffect & & & $0.32(54 \%)$ & & & \\
\hline $\begin{array}{l}\text { CONTR. } 2 \\
\text { (B vs. E, i.e. 0;1;0;0;-1) }\end{array}$ & -3.204 & 0.3203 & -10.005 & 0.0000 & -3.833 & -2.576 \\
\hline${ }^{*}$ SScontrast/SSeffect & & & $0.20(34 \%)$ & & & \\
\hline $\begin{array}{l}\text { CONTR. } 3 \\
\text { (C vs. E, i.e. } 0 ; 0 ; 1 ; 0 ;-1 \text { ) }\end{array}$ & -1.743 & 0.3326 & -5.241 & 0.0000 & -2.395 & -1.091 \\
\hline *SScontrast/SSeffect & & & $0.06(10 \%)$ & & & \\
\hline $\begin{array}{l}\text { CONTR. } 4 \\
\text { (D vs. E, i.e. } 0 ; 0 ; 0 ; 1 ;-1 \text { ) }\end{array}$ & -0.752 & 0.3432 & -2.192 & 0.0285 & -1.425 & -0.079 \\
\hline *SScontrast/SSeffect & & & $0.01(2 \%)$ & & & \\
\hline
\end{tabular}

Source: own work using Statistica software v.12, based on the data from the Educational Research Institute. 
Table 10.

Evaluation of contrasts for classes by the number of pupils taking matura exam dependent variable 'educational value added in mathematics'

\begin{tabular}{|c|c|c|c|c|c|c|}
\hline \multirow[b]{2}{*}{ Specification } & \multicolumn{6}{|c|}{ Educational value added in mathematics } \\
\hline & Evaluation & $\begin{array}{l}\text { Standard } \\
\text { error }\end{array}$ & $t$ & $p$ & $\begin{array}{c}\text { Confidence limit } \\
-95.00 \%\end{array}$ & $\begin{array}{l}\text { Confidence limit } \\
\quad+95.00 \%\end{array}$ \\
\hline $\begin{array}{l}\text { CONTR. } 1 \\
\text { (A vs. E, i.e. } 1 ; 0 ; 0 ; 0 ;-1 \text { ) }\end{array}$ & -5.408 & 0.3042 & -17.776 & 0.0000 & -6.004 & -4.811 \\
\hline *SScontrast/SSeffect & & & $0.27(619$ & & & \\
\hline $\begin{array}{l}\text { CONTR. } 2 \\
\text { (B vs. E, i.e. } 0 ; 1 ; 0 ; 0 ;-1 \text { ) }\end{array}$ & -3.939 & 0.3288 & -11.978 & 0.0000 & -4.583 & -3.294 \\
\hline *SScontrast/SSeffect & & & $0.14(32 \%$ & & & \\
\hline $\begin{array}{l}\text { CONTR. } 3 \\
\text { (C vs. E, i.e. } 0 ; 0 ; 1 ; 0 ;-1)\end{array}$ & -1.842 & 0.3414 & -5.394 & 0.0000 & -2.511 & -1.172 \\
\hline *SScontrast/SSeffect & & & $0.03(79$ & & & \\
\hline $\begin{array}{l}\text { CONTR. } 4 \\
\text { (D vs. E, i.e. } 0 ; 0 ; 0 ; 1 ;-1 \text { ) }\end{array}$ & -0.368 & 0.3523 & -1.045 & 0.2961 & -1.059 & 0.323 \\
\hline *SScontrast/SSeffect & & & $0.00(0 \%$ & & & \\
\hline
\end{tabular}

Source: own work using Statistica software v.12, based on the data from the Educational Research Institute.

Table 11.

Evaluation of contrasts for classes by the number of pupils taking matura exam dependent variable 'educational value added in mathematical and natural sciences'

\begin{tabular}{|c|c|c|c|c|c|c|}
\hline \multirow[b]{2}{*}{ Specification } & \multicolumn{6}{|c|}{ Educational value added in mathematical and natural sciences } \\
\hline & Evaluation & $\begin{array}{l}\text { Standard } \\
\text { error }\end{array}$ & $t$ & $p$ & $\begin{array}{c}\text { Confidence limit } \\
-95.00 \%\end{array}$ & $\begin{array}{l}\text { Confidence limit } \\
\quad+95.00 \%\end{array}$ \\
\hline $\begin{array}{l}\text { CONTR. } 1 \\
\text { (A vs. E, i.e. 1;0;0;0;-1) }\end{array}$ & -6.122 & 0.3213 & -19.054 & 0.0000 & -6.752 & -5.492 \\
\hline *SScontrast/SSeffect & & & $0.28(60 \%$ & & & \\
\hline $\begin{array}{l}\text { CONTR. } 2 \\
\text { (B vs. E, i.e. } 0 ; 1 ; 0 ; 0 ;-1 \text { ) }\end{array}$ & -4.588 & 0.3473 & -13.210 & 0.0000 & -5.269 & -3.907 \\
\hline *SScontrast/SSeffect & & & $0.15(32 \%$ & & & \\
\hline $\begin{array}{l}\text { CONTR. } 3 \\
\text { (C vs. E, i.e. } 0 ; 0 ; 1 ; 0 ;-1)\end{array}$ & -2.194 & 0.3606 & -6.084 & 0.0000 & -2.901 & -1.487 \\
\hline *SScontrast/SSeffect & & & $0.04(9 \%$ & & & \\
\hline $\begin{array}{l}\text { CONTR. } 4 \\
\text { (D vs. E, i.e. } 0 ; 0 ; 0 ; 1 ;-1 \text { ) }\end{array}$ & -0.547 & 0.3722 & -1.471 & 0.1415 & -1.277 & 0.182 \\
\hline *SScontrast/SSeffect & & & $0.00(0 \%$ & & & \\
\hline
\end{tabular}

Source: own work using Statistica software v.12, based on the data from the Educational Research Institute. 
Figure 1.

Distribution of schools belonging to class $\mathrm{D}$ and $\mathrm{E}$ (the most effective teaching process)

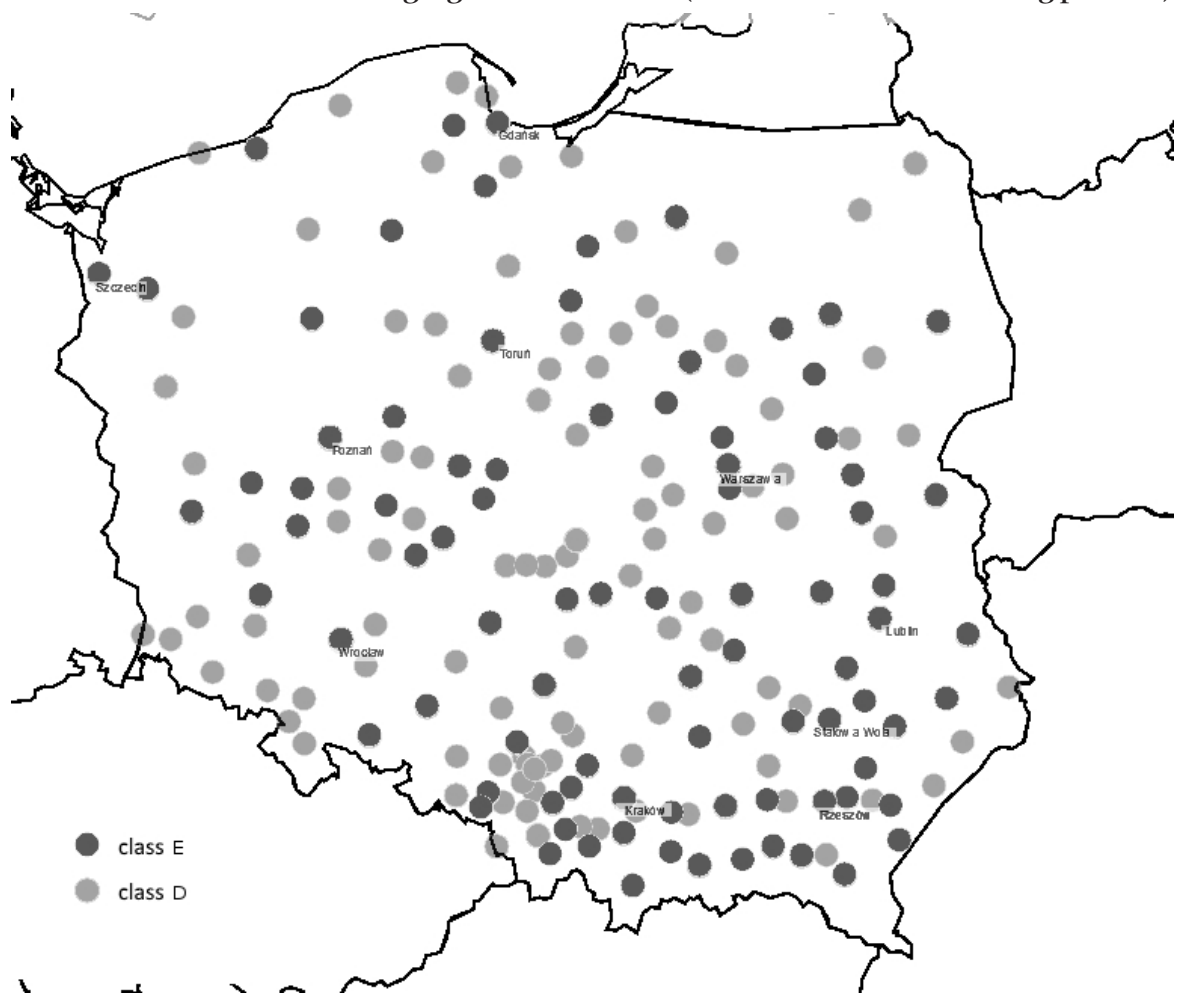

Source: own work based on the analysed data. 